\title{
Quail performance and egg quality at the end of production fed with varying levels of calcium
}

\section{Desempenho e qualidade de ovos de codornas em final de produção alimentadas com níveis crescentes de cálcio}

\author{
Daniele Santos de Souza ${ }^{1 *}$; Lígia Fátima Lima Calixto²; Marina Jorge de Lemos ${ }^{3}$; \\ Carlos Alberto da Silva Filho,; Thiers Pascoal Pinho4; Cleriston Andrade Machado ${ }^{4}$; \\ Izaura Andrade de Melo ${ }^{5}$ Cristina Kimie Togashi ${ }^{6}$
}

\begin{abstract}
The goal of the present study was to evaluate the influence of increasing levels of dietary calcium on performance, egg quality, and the amount of calcium retained in the meat and excreted by Japanese quails at the final production. Four hundred 46-58-week-old Japanese quails were distributed in a completely randomized design consisting of five calcium level treatments: $\mathrm{T} 1=2.95 \%, \mathrm{~T} 2=3.25 \%$, T3 $=3.55 \%, \mathrm{~T} 4=3.85 \%$ and $\mathrm{T} 5=4.15 \%$ calcium. The performance variables included feed intake $\left(\mathrm{g} \mathrm{bird}^{-1}\right.$ day $\left.^{-1}\right)$, egg production (\%), feed conversion by egg mass and per dozen eggs, egg mass (g), and viability. For egg quality, we assessed egg weight, percentage of albumen, yolk weight, percentage of shell, and shell thickness. We also evaluated the amount of calcium present in the meat and the amount of calcium excreted by quails. Increasing levels of calcium linearly influenced feed conversion, weight of yolk, and percentage of eggshell. Shell thickness increased up to the $3.85 \%$ calcium treatment. Calcium content of the meat differed among the quails; the quails fed the lowest level of calcium (2.95\%) showed higher calcium content in meat, whereas calcium excretion increased with increasing levels of calcium in the diet. In conclusion, the addition of $3.85 \%$ of calcium in quail feed at the end of production improved eggshell quality, and maintained internal quality and performance within the recommended standards for the production phase tested in quails. Levels higher than 3.85\% calcium negatively influenced the parameters analyzed.
\end{abstract}

Key words: Coturnix coturnix japonica. Digestibility. Eggshell thickness.

\section{Resumo}

O objetivo do presente estudo foi avaliar a influência de níveis crescentes de cálcio na dieta sobre o desempenho, a qualidade do ovo, e a quantidade de cálcio retido na carne e excretado por codornas japonesas em final da produção. Quatrocentas codornas japonesas de 46-58 semanas de idade foram

\footnotetext{
${ }^{1}$ Discente do Curso de Mestrado do Programa de Pós-Graduação em Zootecnia, Universidade Federal Rural do Rio de Janeiro, UFRRJ, Seropédica, RJ, Brasil. E-mail: danyssz@gmail.com

2 Prof A Associada, UFRRJ, Seropédica, RJ, Brasil. E-mail: 1flcalixto@uol.com.br

${ }^{3}$ Discente do Curso de Doutorado do Programa de Pós-Graduação em Zootecnia, UFRRJ, Seropédica, RJ, Brasil. E-mail: marijorgelemos@hotmail.com

${ }^{4}$ Discentes do Curso de Graduação em Zootecnia, UFRRJ, Seropédica, RJ, Brasil. E-mail: camusrj@gmail.com; thiers_pinho@ hotmail.com; cleriston.andrade@yahoo.com.br

${ }^{5}$ Discente do Curso de Graduação em Medicina Veterinária, UFRRJ, Seropédica, RJ, Brasil. E-mail: izauraamelo@zootecnista. com.br

${ }^{6}$ Prof $^{a}$ Adjunto, Universidade Federal Fluminense, UFF, Niterói, RJ, Brasil. E-mail: cristinatogashi@id.uff.br

* Author for correspondence
} 
distribuídas em um delineamento experimental inteiramente casualizado, sendo os tratamentos constituídos de cinco níveis de cálcio: $\mathrm{T} 1=2,95 \%, \mathrm{~T} 2=3,25 \%$, T3 $=3,55 \%, \mathrm{~T} 4=3,85 \%$ e T5 =4,15\%. As variáveis de desempenho incluíam o consumo de ração (g/ave/dia), produção de ovos (\%), conversão alimentar por massa de ovo e por dúzia de ovos, massa de ovo (g), e viabilidade. Para a qualidade dos ovos foram avaliados o peso dos ovos, porcentagem de albúmen, peso da gema, porcentagem de casca e espessura da casca. Também foi avaliada a quantidade de cálcio presente na carne e a quantidade de cálcio excretado pelas codornas. O aumento dos níveis de cálcio influenciou linearmente a conversão alimentar, o peso de gema e a porcentagem de casca de ovo. A espessura da casca aumentou até o nível de inclusão de $3,85 \%$ de cálcio. O teor de cálcio da carne diferiu entre as codornas; as codornas alimentadas com o menor nível de cálcio (2,95\%) apresentaram maior teor de cálcio na carne, enquanto a excreção de cálcio aumentou com o aumento dos níveis de cálcio na dieta. Em conclusão, a adição de $3,85 \%$ de cálcio na alimentação de codornas no final da produção melhorou a qualidade da casca do ovo, e manteve a qualidade interna e o desempenho dentro dos padrões recomendados para a fase de produção estudada nesta espécie. Níveis superiores a 3,85\% de cálcio influenciaram negativamente os parâmetros analisados.

Palavras-chave: Coturnix coturnix japonica. Digestibilidade. Espessura de casca.

\section{Introduction}

Factors such as rapid growth, earlier sexual maturity and egg production (35 to 42 days), higher egg productivity, and greater longevity (14 to 18 months), and quicker economic returns have led to large scale production of laying quails in Brazil, which is currently the second largest quail producer. According to the IBGE (2013), Brazilian quail production increased by $10.6 \%$ during 2012 , and the production of eggs was $20.2 \%$ higher compared to the previous year. The southeastern region contributed to the largest production in the country, accounting for $82.7 \%$ of the national production.

With advancing quail age, production decreases with an associated increase in egg weight, and shell composition and thickness also change (MÁCHAL; SIMEONOVOVÁ, 2002). The increase in egg weight ratios can be up to $20 \%$; however, there is no proportional increase in the weight of the shell because the calcium present in the shell is distributed over a larger surface. Concomitantly, older laying quails absorb less calcium because of a reduction in the retention capacity of this mineral in the gut and increased mobilization of bone calcium, leading to increased production of eggs with thinner shells that chip or break more easily. However, when extra calcium is fed to quails with the lowest retention capacity, calcium passes through the digestive tract more quickly without being absorbed, which increases the rate of calcium excretion (KESHAVARZ; NAKAJIMA, 1993; ITO et al., 2006; PELÍCIA, 2008; MURATA et al., 2009; CARVALHO; FERNANDES, 2013).

Layers are sensitive to alterations in nutrient levels in their diet, especially calcium levels. High levels can cause reduced feed intake because quails have the ability to regulate the intake of this mineral in relation to their nutritional requirements. The regulation may occur because of reduced palatability of feed and increased excretion rate (OLIVEIRA; ALMEIDA, 2004; VARGAS JÚNIOR et al., 2004; SILVA, 2011).

Several studies have evaluated the influence of the incorporation of increasing levels of calcium in quail diet, but few studies have evaluated these parameters in quails at the end of production. This is the stage when there could be greater influence on eggshell thickness, as explained above. Therefore, the present study was conducted to evaluate the influence of increasing levels of dietary calcium on performance, egg quality, the amount of calcium retained in the meat and excreted by Japanese quails at the final production. 


\section{Materials and Methods}

The experiment was conducted at the Poultry sector of the Rural Federal University of Rio de Janeiro (UFRRJ) between the months of March and May, with the study divided into four periods each of 21 days. We used 400 46-58-week-old Japanese quails, distributed in a completely randomized design consisting of five calcium level treatments: $\mathrm{T} 1=2.95 \%, \mathrm{~T} 2=3.25 \%, \mathrm{~T} 3=$ $3.55 \%, \mathrm{~T} 4=3.85 \%$, and $\mathrm{T} 5=4.15 \%$ calcium with 10 repetitions of eight quails per repetition. Diets were formulated with corn and soybean meal to meet the minimum nutritional requirements, according to Rostagno et al. (2011), except for calcium levels (Table 1).

Table 1. Percentage and nutritional composition calculated for the experimental diets.

\begin{tabular}{|c|c|c|c|c|c|}
\hline \multirow[b]{2}{*}{ Ingredients } & \multicolumn{5}{|c|}{ Treatments } \\
\hline & $2.95 \%$ & $3.25 \%$ & $3.55 \%$ & $3.85 \%$ & $4.15 \%$ \\
\hline Ground corn & 49.635 & 49.635 & 49.635 & 49.635 & 49.635 \\
\hline Soybean meal & 34.479 & 34.479 & 34.479 & 34.479 & 34.479 \\
\hline Limestone & 6.747 & 7.528 & 8.309 & 9.091 & 9.872 \\
\hline Soy oil & 3.671 & 3.671 & 3.671 & 3.671 & 3.671 \\
\hline Kaolin & 3.400 & 2.600 & 1.800 & 1.000 & 0.200 \\
\hline Dicalcium phosphate & 1.066 & 1.066 & 1.066 & 1.066 & 1.066 \\
\hline DL-Methionine & 0.349 & 0.349 & 0.349 & 0.349 & 0.349 \\
\hline Salt & 0.325 & 0.325 & 0.325 & 0.325 & 0.325 \\
\hline L-Lysine $\mathrm{HCl}$ & 0.124 & 0.124 & 0.124 & 0.124 & 0.124 \\
\hline Vitamin supplement & 0.100 & 0.100 & 0.100 & 0.100 & 0.100 \\
\hline Mineral supplement & 0.100 & 0.100 & 0.100 & 0.100 & 0.100 \\
\hline Total & 100.00 & 100.00 & 100.00 & 100.00 & 100.00 \\
\hline \multicolumn{6}{|l|}{ Nutritional composition } \\
\hline Metabolizable Energy (kcal / kg) & 2800 & 2800 & 2800 & 2800 & 2800 \\
\hline Crude Protein $(\%)$ & 20.00 & 20.00 & 20.00 & 20.00 & 20.00 \\
\hline Calcium $(\%)$ & 2.95 & 3.25 & 3.55 & 3.85 & 4.15 \\
\hline Available phosphorus (\%) & 0.303 & 0.303 & 0.303 & 0.303 & 0.303 \\
\hline Methionine and cystine Dig (\%) & 0.876 & 0.876 & 0.876 & 0.876 & 0.876 \\
\hline Dig Methionine (\%) & 0.606 & 0.606 & 0.606 & 0.606 & 0.606 \\
\hline Total Methionine (\%) & 0.632 & 0.632 & 0.632 & 0.632 & 0.632 \\
\hline Lysine Dig (\%) & 1.077 & 1.077 & 1.077 & 1.077 & 1.077 \\
\hline Lysine Total (\%) & 1.174 & 1.174 & 1.174 & 1.174 & 1.174 \\
\hline
\end{tabular}

Composition per $\mathrm{kg}$ of product 1.2: 1 vitamin A (min) 7,500,000 IU kg-1; vitamin D3 (min) 2,500,000 IU kg-1; vitamin E (min) $1.200 \mathrm{mg} \mathrm{kg}^{-1}$; vitamin $\mathrm{K} 3(\mathrm{~min}) 1.200 \mathrm{mg} \mathrm{kg}^{-1}$; thiamine (min) $1.500 \mathrm{mg} \mathrm{kg}^{-1}$; riboflavin (min) $5.500 \mathrm{mg} \mathrm{kg}^{-1}$; pyridoxine (min) $2000 \mathrm{mg} \mathrm{kg}^{-1}$; vitamin B12 (min) $12000 \mathrm{mcg} \mathrm{kg}^{-1}$; niancina $35 \mathrm{~g} \mathrm{~kg}^{-1}$; calcium panteonato (min) $10 \mathrm{~g} \mathrm{~kg}^{-1}$; biotin (min) 67 mg kg-1; 202 iron (min) $60 \mathrm{~g} \mathrm{~kg}^{-1}$; copper (min) $13 \mathrm{~g} \mathrm{~kg}^{-1}$; manganese (min) $120 \mathrm{~g} \mathrm{~kg}^{-1}$; zinc (min) $100 \mathrm{~g} \mathrm{~kg}^{-1}$; iodine (min) $2.500 \mathrm{mg} \mathrm{kg}$; selenium (min) $500 \mathrm{mg} \mathrm{kg}^{-1}$.

The quails were housed in a $11 \mathrm{~m} \times 6 \mathrm{~m}$ closed brick shed that was covered with clay tiles. It had rocker type windows and a cement floor, and quails were housed in two rows of a battery of five galvanized steel floors with cages that were 100 $\mathrm{cm}$ long $\times 33 \mathrm{~cm}$ deep $\times 15 \mathrm{~cm}$ high (the length was divided into three equal divisions of 33.33 $\mathrm{cm})$. Each cage contained a feeder-type rail, nipple- 
type water dispenser, egg catchers, and collecting trays for excreta. Water and feed were given ad libitum, and the feed was supplied at two times (morning and afternoon) to stimulate consumption. The management and equipment used were the standard for the propagation of Japanese quail, and they were allowed to adapt to the conditions of the experimental shed.

We used a $16 \mathrm{~h}$ light:8 $\mathrm{h}$ dark photoperiod. The lights were controlled by an automatic timer that turned the lights off at night and on in the morning; this procedure was adopted from commercial farms. Quails remained for seven days in the process of adaptation to experimental diets, and after this period began collecting data.

We recorded temperatures in the shed twice a day, and the average maximum and minimum were $37.5^{\circ} \mathrm{C}$ and $25.7^{\circ} \mathrm{C}$, respectively. The average relative humidity was $66 \%$ and was recorded daily using a digital thermo hygrometer located at a central point in the shed. The variables evaluated for performance were: feed intake ( $\mathrm{g} \mathrm{bird}^{-1}$ day $\left.^{-1}\right)$, egg production (\%), feed conversion mass and per dozen eggs produced, and egg mass (g) and viability. For egg quality, we assessed egg weight, percentage of albumen, yolk weight, percentage of shell, and shell thickness. We also evaluated the amount of calcium present in the meat and the amount of calcium excreted by quails.

For egg quality, evaluations were performed at 21-day intervals in the Animal Products Analysis Laboratory Animal Science Institute of the Federal Rural University of Rio de Janeiro. Twenty eggs were collected from each treatment, three eggs per replicate for three consecutive days, totaling 450 units evaluated for each 21-day interval. For all analyzes for the quality of eggs, except for measures of weight and thickness of the shell, the evaluations were performed on the day of collection.

After collection, the eggs were sent to the laboratory where they were weighed on a digital scale with a precision of $0.01 \mathrm{~g}$. At the end of the experiment, we calculated the mean values for each period. After weighing, the eggs were broken on a flat piece of glass, egg yolks were separated from the albumen and shell. The yolks were washed to remove albumin residue and dried at room temperature for $24 \mathrm{~h}$ before weighing. The weight of the albumen was obtained by the formula: Weight $=$ albumen egg weight - (shell weight + weight of the yolk).

Shell thickness was measured after drying the samples using an analog Mitutoyo micrometer. Thickness values were obtained by measuring two shell fragments from the equatorial zone and the final value was obtained by averaging these two points.

For determination of calcium present in the quail meat samples at the end of the experiment, 20 birds (58 week old) per treatment (100 birds total) with an average weight of $200 \mathrm{~g}$ were selected. The birds were individually identified by tags and fasted for $8 \mathrm{~h}$. After fasting, they were sacrificed by cervical dislocation and separated into two groups for analytical determination of calcium in the meat. The analysis was conducted at the Food Technology Institute of UFRRJ. The meat was subjected to the method of the Association of Analytical Chemists (AOAC, 2005) to obtain the level of ash, wherein a $2 \mathrm{~g}$ meat sample was placed in a muffle at $550^{\circ} \mathrm{C}$ for $3 \mathrm{~h}$ or until light gray. For determinations of $\mathrm{Ca}$ in ash, we followed the IAL (1985). The measurement was conducted by flame photometer using a bank of reagents in parallel for each analysis.

The determination of calcium excretion rate was conducted during the last five days of the trial period, using the excreta collection method (SIBBALD; SLINGER, 1963). Quails continued to receive water and feed ad libitum throughout the collection period. The collections were conducted twice a day, at 07:00 $\mathrm{h}$ and 18:00 $\mathrm{h}$, to avoid possible fermentation. To facilitate the collection of excreta and prevent loss of material, the drip pans for excreta were lined with plastic bags, which served 
as a storage area for excreta in each repetition. After removal of feathers, feed waste, and other sources of contamination, the remaining material was transferred to properly identified plastic bags and transported to the Animal Products Laboratory UFRRJ. Sampled were homogenized by treatment, stored in batches of $500 \mathrm{~g}$ and frozen until the end of the total collection period, when they were dried in an oven at $105^{\circ} \mathrm{C}$ for a period of $72 \mathrm{~h}$. Next, the samples were frozen, packaged, and appropriately identified to avoid being damaged and maintained for 90 days. The samples were subjected to another drying in an oven to remove excess moisture and then were ground, placed in properly labeled plastic pots, and kept in the laboratory at room temperature for 45 days. At the end of that period, they were subjected to analysis according to the methods described by Silva and Queiroz (2002). The excreted calcium was measured using a flame photometer (Microprocessed Analyser) in the Food Technology Institute of UFRRJ, and the amount of calcium excreted by the quails in each treatment was determined.

The results were assessed by analysis of variance (ANOVA), with the treatment means compared by Tukey's test at 5\% significance using the BioEstat Program. The effects of calcium levels on performance, egg quality, and calcium content retained in the flesh were estimated by linear and quadratic regression, and the best fit was obtained for each variable.

\section{Results and Discussion}

The effect of the calcium on the performance variables are presented in Table 2. Feed intake was not affected by increasing levels of calcium in the diet $(\mathrm{P}>0.05)$. High calcium levels could reduce food intake. This can be explained by the fact that quails regulate calcium intake similar to the regulation of energy and protein (COSTA, 2010). In the present study, we did not observe reduced food consumption. According to Oliveira and Almeida (2004), quails are more tolerant to calcium variations, and excrete excess of this mineral more efficiently compared to other species. Similar results were found by Pizzolante et al. (2007), who tested diets containing different levels of calcium $(1.25 \%$, $2.50 \%$, and $3.75 \%$ ) in 54-week-old Japanese quails; Costa (2010), evaluated the effect of calcium levels $(2.2 \%, 2.6 \%, 3.0 \%, 3.4 \%$, and $3.8 \%)$ in the diets of 45-57-week-old Japanese quail; . and Silva (2011) tested levels of $2.0 \%, 2.5 \%, 3.0 \%$, and $3.5 \%$ calcium in 39-54-week-old Japanese quails. However, Garcia et al. (2000) studied calcium levels (2.5\% to $4.0 \%$ ) in isocaloric, isoproteic, and isoaminoacid methionine + cystine feed in 10-week-old Japanese quails and found that increasing calcium levels caused a linear reduction in consumption of ration.

Table 2. Performance of Japanese quails fed diets with increasing levels of calcium in the final production.

\begin{tabular}{|c|c|c|c|c|c|c|c|c|}
\hline \multirow{2}{*}{ Parameters } & \multicolumn{8}{|c|}{ Calcium level (\%) } \\
\hline & 2.95 & 3.25 & 3.55 & 3.85 & 4.15 & Effect & CV (\%) & MEAN \\
\hline Feed intake (g quail ${ }^{-1}$ day $\left.^{-1}\right)$ & 24.79 & 24.71 & 25.11 & 24.65 & 24.84 & ns & 6.58 & 24.82 \\
\hline$\%$ production & 81.56 & 79.49 & 82.08 & 80.00 & 79.64 & ns & 1.47 & 80.56 \\
\hline $\mathrm{CA} \mathrm{kg} \mathrm{kg}^{-1}$ & 3.43 & 3.41 & 3.36 & 3.33 & 3.29 & $\mathrm{~L}$ & 3.98 & 3.37 \\
\hline $\mathrm{CA} \mathrm{kg} \mathrm{dz}^{-1}$ & 0.371 & 0.397 & 0.397 & 0.384 & 0.397 & ns & 2.99 & 0.390 \\
\hline MO (g quail ${ }^{-1}$ day $\left.^{-1}\right)$ & 9.95 & 9.49 & 9.49 & 9.48 & 9.43 & ns & 2.25 & 9.57 \\
\hline Viability (\%) & 88.90 & 88.92 & 89.17 & 89.18 & 87.13 & ns & 0.98 & 88.67 \\
\hline
\end{tabular}

L- significant for linear regression; NS- not significant; CA - feed conversion; MO - egg mass; CV - coefficient of variation 
The percentage of production was not affected ( $\mathrm{P}$ $>0.05$ ) by increasing levels of calcium. The lack of influence of the incorporation of increasing levels of calcium in the diet on egg production was also previously observed by several authors: Barreto et al. (2007) who tested calcium levels $(1.65 \%, 2.05 \%$, $2.4 \%, 2.8 \%, 3.2 \%$, and $3.6 \%$ ) in 8-24-week-old Japanese quails and Silva (2011) that tested calcium levels $(2.0 \%, 2.5 \%, 3.0 \%$, and $3.5 \%)$ in 7-54-weekold Japanese quails. However, Luz (2002) evaluated the effect of increasing calcium levels $(2.0 \%, 2.5 \%$, $3.0 \%$, and $3.5 \%$ ) in 8-28-week-old quails and found that egg production increased linearly with increasing levels of calcium in the diet.

A linear effect was observed for feed conversion on egg mass $\left(y=4.2017-0.2467 x ; R^{2}=0.78\right)$, which illustrates the improvement in feed conversion with increased calcium levels in the diet $(\mathrm{P}<0.05)$ (Figure 1). Because there was no effect on feed intake, egg production, and egg mass, the improvement of this parameter was similar to that of higher percentage and thickness of shells (Table 3). This result corroborates the findings of Luz (2002) who reported improved feed conversion to egg mass with elevated calcium levels $(2.0 \%, 2.5 \%, 3.0 \%$, and $3.5 \%)$ in the diet of 8-28-week-old Japanese quails. Barreto et al. (2007) evaluated the inclusion levels $(1.6 \%, 2.0 \%, 2.4 \%$, $2.8 \%, 3.2 \%$, and $3.6 \%$ ) in the diet of $8-24$-weekold Japanese quails during the production phase and found that feed conversion to egg mass was improved as calcium levels increased. Conversely, they are not consistent with the results of Garcia et al. (2000) who studied the nutritional requirements of calcium $(2.5 \%, 3.0 \%, 3.5 \%$, and $4.0 \%)$ and phosphorus in 10 -week-old Japanese quails.

Figure 1. Feed conversion by egg mass on the basis of calcium levels in Japanese quails.

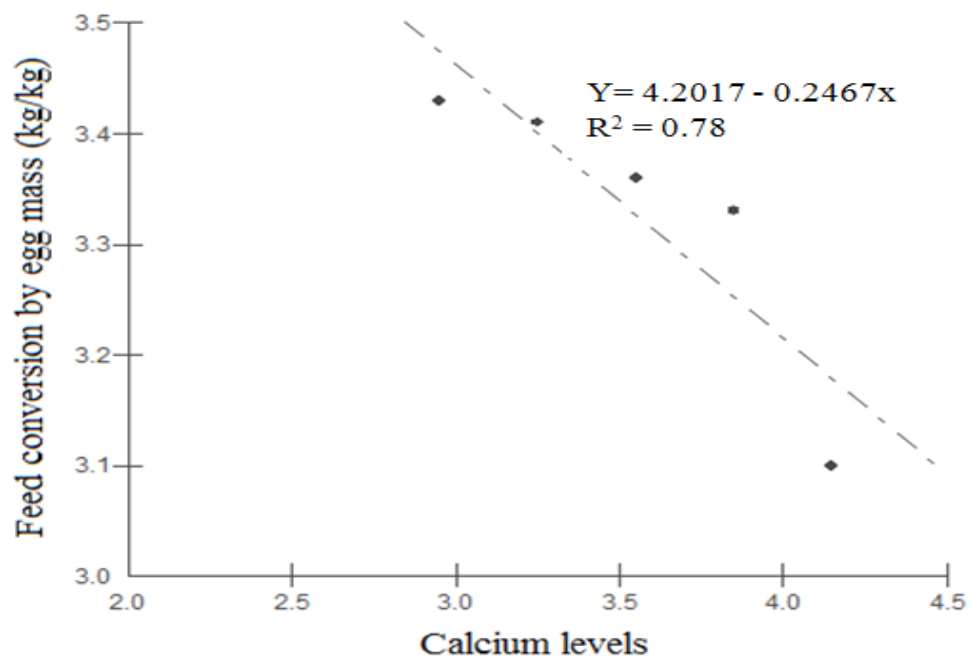

Table 3. Egg quality produced by Japanese quails fed diets with increasing levels of calcium, at the end of production.

\begin{tabular}{lcccccccc}
\hline \multicolumn{1}{c}{ Parameters } & \multicolumn{1}{c}{ Calcium Level (\%) } \\
\cline { 2 - 9 } Egg weight $(\mathrm{g})$ & $\mathbf{2 . 9 5}$ & $\mathbf{3 . 2 5}$ & $\mathbf{3 . 5 5}$ & $\mathbf{3 . 8 5}$ & $\mathbf{4 . 1 5}$ & Effect & CV(\%) & MEAN \\
Yolk weight $(\mathrm{g})$ & 12.20 & 11.94 & 11.57 & 11.85 & 11.85 & ns & 4.75 & 11.88 \\
\% albumen & 3.82 & 3.79 & 3.73 & 3.72 & 3.69 & $\mathrm{~L}$ & 1.42 & 3.75 \\
\% shell & 60.87 & 60.67 & 59.61 & 60.38 & 60.82 & $\mathrm{~ns}$ & 0.86 & 60.47 \\
EC (mm) & 7.824 & 7.588 & 8.149 & 8.228 & 8.041 & $\mathrm{~L}$ & 5.72 & 7.97 \\
\hline
\end{tabular}

Q- significant for quadratic regression; L- significant for linear regression; EC-shell thickness; NS not significant; CV- coefficient of variation. 
Feed conversion per dozen eggs was not affected by calcium levels $(\mathrm{P}>0.05)$. This result followed the results observed for the percentage of production in the present study, which was not influenced by increasing levels of dietary calcium. Similar results were found by Costa et al. (2008) who evaluated calcium levels $(3.0 \%, 3.4 \%, 3.8 \%, 4.2 \%, 4.6 \%$, and 5.0\%) in laying hens after peak production and Barreto et al. (2007) evaluated calcium levels (1.6\%, $2.0 \%, 2.4 \%, 2.8 \%, 3.2 \%$, and $3.6 \%$ ) in the diets of 8-24-week-old Japanese quails during production phase.

The egg mass and viability were not affected by calcium levels $(\mathrm{P}>0.05)$. These results were similar to those reported by Costa et al. (2008) who tested different levels of calcium (2.5 and 3.2\%).

The effect of calcium levels tested on the variables related to the quality of eggs are described in Table 3. Egg weight was not influenced ( $\mathrm{P}>$ $0.05)$ by increasing levels of calcium. According Masukawa et al. (2001), excess calcium did not always positively influence the performance of the birds, and older laying birds absorbed less calcium because of a reduction in the retention capacity of this mineral in the gut (ITO et al., 2006; MURATA et al., 2009). The supply of excess mineral can lead to the passage of this nutrient more quickly through the digestive tract without it being absorbed (PELÍCIA, 2008). The results of this study corroborate the findings of Masukawa et al. (2001), Pizzolante et al. (2007), Costa et al. (2008), and Costa (2010). However, Garcia et al. (2000) investigated the nutritional requirements of calcium $(2.5 \%, 3.0 \%, 3.5 \%$, and $4.0 \%$ ) and phosphorus in 10-week-old Japanese quails and Silva (2011) evaluated calcium levels $(2.0 \%, 2.5 \%, 3.0 \%$, and $3.5 \%)$ and phosphorus in the diet of Japanese quails at different stages of the production cycle, they found that calcium levels influenced the average weight of eggs, with the lowest level of calcium resulting in heaviest eggs.

The percentage of albumen was not influenced by increasing levels of calcium $(\mathrm{P}>0.05)$. There was a linear decrease $\left(y=4.1405-0.1100 x ; R^{2}=0.95\right)$ in calcium levels only for egg yolk weight (Figure 2) $(P<0.05)$, namely, as calcium levels increased, weight of the egg yolk decreased. According to the literature, there may be interference from high levels of calcium in the calcium phosphorus ratio. According to Scherer et al. (2004) and Costa (2010), excess calcium in the diet may interfere with the availability of other minerals, such as phosphorus. Pelícia (2008) stated the major portion of the absorbed phosphorus is incorporated into the yolk during the process of egg formation in the form of phospholipids and phosphoproteins; therefore, a change in the availability of this nutrient could reduce the percentage yolk. These results agree with the results cited by Costa (2010), who evaluated the effect of calcium and phosphorus levels in diets of 45-57-week-old Japanese quails, and found no effect of calcium levels $(2.2,2.6,3.0,3.4$, and 3.8\%) on the percentage of albumen and yolk, but found a significant effect on yolk weight.

The percentage of shell increased $(\mathrm{P}<0.05)$ with an increase in calcium levels in the diet, demonstrating the behavior expressed by the linear function $\mathrm{y}=0.3947 \mathrm{x}+6.5753, \mathrm{R}^{2}=0.62$ (Table 3 and Figure 3 ). These results are consistent with those found by Barreto et al. (2007) who studied increasing calcium levels (1.6, 2.0, 2.4, 2.8, 3.2, and $3.6 \%$ ) in the diet of Japanese quails, and observed an increase in the percentage of shell as calcium levels increased. 
Figure 2. Yolk weight of eggs of Japanese quails fed various levels of calcium

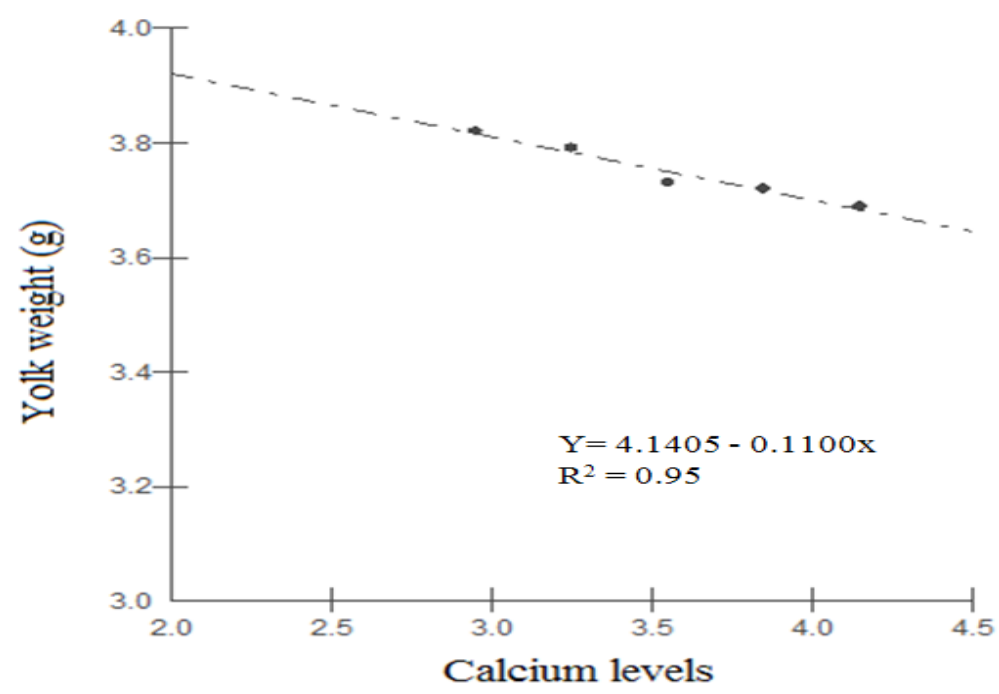

Figure 3. Shell percentage of eggs of Japanese quails fed various levels of calcium.

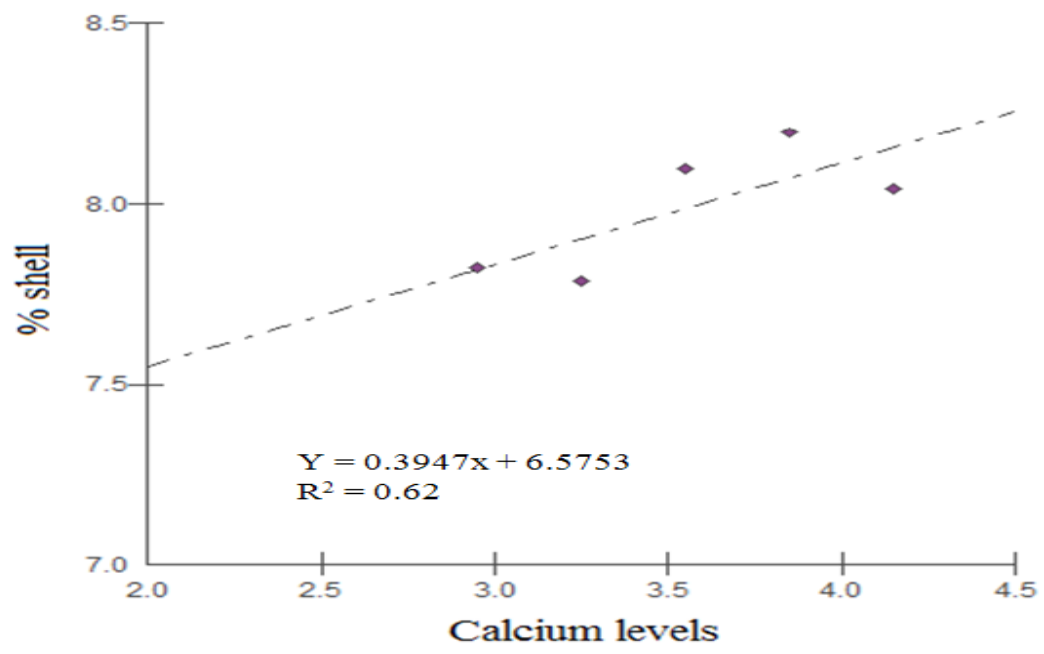

Shell thickness was influenced by the increase in calcium levels in the diet $(\mathrm{P}<0.05)$ (Table 3 and Figure 4). A quadratic effect was observed $\left(\mathrm{y}=-0.0278 \mathrm{x} 20.2056 \mathrm{x}+-0.1875 ; \mathrm{R}^{2}=0.79\right)$ and increased shell thickness occurred up to the $3.85 \% \mathrm{Ca}$ treatment. Higher levels of calcium caused a reduction of shell thickness. The supply of $\mathrm{Ca}$ above the recommended levels can improve the quality of the eggshell in the final third of the production cycle (COSTA, 2010). However, according to Maiorka and Macari (2002), when in excess, absorption and consequently utilization might be impaired because, according to Simões (2009), the kidneys increase calcitonin elimination through the urine, stimulating its deposition in bone and reduced intestinal absorption. The results for calcium excretion in this study supported this, because when there was an increased level of calcium in the diet, calcium excretion was higher (Figure 5). 
Figure 4. Shell thickness of eggs of Japanese quails fed various levels of calcium.

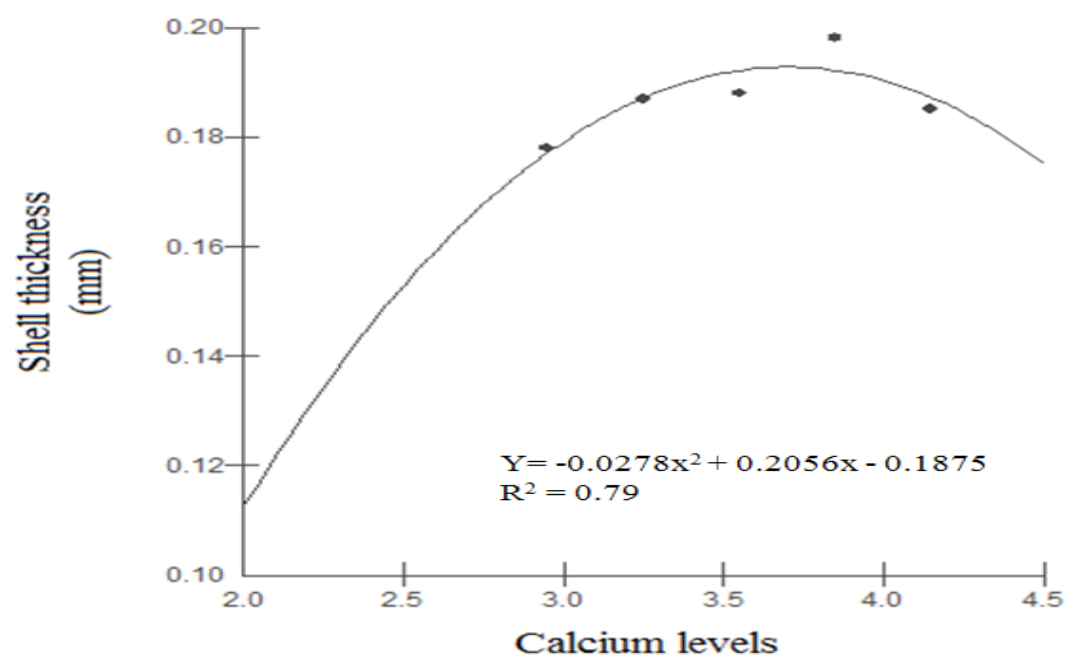

Similar results were observed by Costa (2010), who studied calcium levels $(2.2 \%, 2.6 \%, 3.0 \%$, $3.4 \%$, and $3.8 \%$ ) in the diet of $45-57$-week-old Japanese quails in the final third of production and found that increasing calcium levels in the diet improved the percentage and thickness of shells.

The results for the effect of calcium levels on the calcium in meat and that excreted from Japanese quails are shown in Table 4 and Figure 5. The calcium content in the meat of Japanese quails fed increasing levels of this mineral was different $(\mathrm{P}<0.05)$, and quails fed the lowest level of calcium $(2.95 \%)$ showed the higher calcium content in the meat. The birds fed diets containing levels higher than $2.95 \%$ had lower average calcium content in meat, but the difference was not significant. The increase in calcium in the diet could cause decreased protein biosynthesis and carrier duodenal calcium levels and decreased absorption efficiency of the mineral, with an improved efficiency achieved at lower levels of intake (BERTECHINI, 2006).

Table 4. Average calcium content in the meat of Japanese quails fed with increasing levels of calcium in the final production.

\begin{tabular}{cc}
\hline Treatments $(\% \mathrm{Ca})$ & $\mathrm{mg} / 100 \mathrm{~g}$ of meat \\
\hline 2.95 & $14.2^{\mathrm{a}}$ \\
3.25 & $10.5^{\mathrm{b}}$ \\
3.55 & $10.2^{\mathrm{b}}$ \\
3.85 & $9.3^{\mathrm{b}}$ \\
4.15 & $9.4^{\mathrm{b}}$ \\
\hline CV $(\%)$ & 18.77 \\
\hline MEAN & 10.72 \\
\hline
\end{tabular}

Averages in the same column followed by the same letter do not differ $(\mathrm{P}>0.05)$ by Tukey's test. 
Figure 5. Calcium quantity excreted by Japanese quails fed various calcium levels

Calcium quantity excreted by Japanese quails

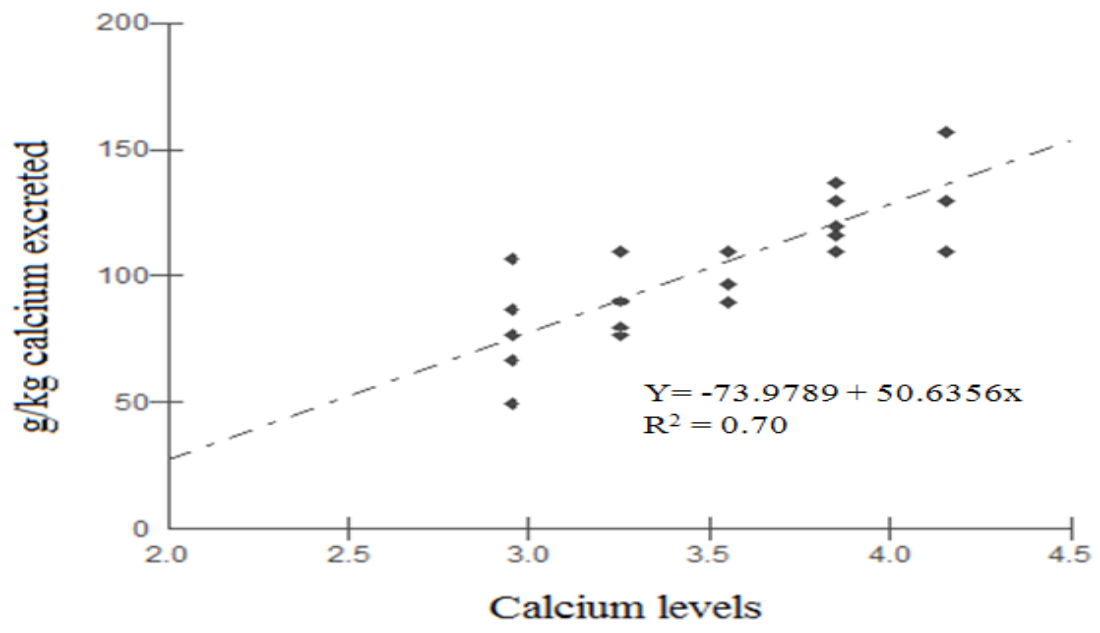

When an increase in the level of calcium in the diet, the calcium content in meat decreased, but there was improvement in shell quality through increased thickness and percentage of eggshell (Table 3). This emphasized that the age of quails tends to promote lower absorption and retention of this mineral, which is also reflected in the poor quality of the shells. In this study, these assumptions were supported by our results for production of eggs, which was not influenced by increasing dietary calcium levels (Table 2). A part of the absorbed calcium was directed to the formation of a more resistant shell, another part was retained in the meat of the quails, and a fraction was discarded by the organism in the feces (Figure 5); we observed a greater rate of calcium excretion with the increase in calcium levels in the diet. Similar results were found by Lima (2011), who observed that the higher the calcium intake, the lower the amount of calcium retained in the housing because the ingestion of high daily calcium concentration decreases absorption because of the saturation of calcium transporting proteins.

Calcium excretion in feces was increased by higher calcium levels in the diet of the quails, with the behavior expressed by a linear function $(\mathrm{Y}=$ $\left.-73.9787+50,6356 x ; R^{2}=0.70\right)(P<0.05)$. The increased level of calcium in the diet might lead to an increase in the rate of excretion of the mineral (COSTA, 2010). When calcium levels in the diet are low, there is a higher production of calciumbinding protein, which participates in increased absorption and utilization of the mineral; however, higher utilization occurs only up to a certain level because excess calcium in the diet can reduce absorption (DELL'ISOLA; BAIÃO, 2001). In older birds, intestinal calcium absorption capacity tends to decrease because of reduced activity of calciumbinding proteins (COSTA, 2010); however, in this study, increasing levels up to $3.85 \%$ promoted improved shell quality of eggs without causing interference in feed intake or egg production. Similar results were found by Costa (2010) who studied calcium levels $(2.0 \%, 2.5 \%, 3.0 \%$, and $3.5 \%$ ) in the diet of 45-57-week-old Japanese quails at the end of last third of production and found that increasing calcium levels in the diet resulted in a higher amount of calcium excreted.

\section{Conclusion}

In conclusion, the addition of $3.85 \%$ of calcium in quail feed at the end of production improved eggshell quality, while maintaining internal quality 
and animal performance within the recommended standards for the production phase tested in Japanese quails. Calcium levels higher than $3.85 \%$ negatively influenced the parameters analyzed.

\section{Acknowledgments}

The authors would like to thank the CAPES (Coordenação de Aperfeiçoamento de Pessoal de Nível Superior) for the Master's scholarship.

\section{References}

ASSOCIATION OF OFFICIAL ANALYTICAL CHEMISTS - AOAC. Official Methods of Analysis. $15^{\text {th }}$ ed. Arlington: AOAC, 2005.

BARRETO, S. L. T.; PEREIRA, C. A.; UMIGI, R. T.; ROCHA, T. C.; ARAUJO, M. S.; SILVA, C. S.; TORRES FILHO, R. A. Determinação da exigência nutricional de cálcio de codornas japonesas na fase inicial do ciclo de produção. Revista Brasileira de Zootecnia, Viçosa, MG, v. 36, n. 1, p. 68-78, 2007.

BERTECHINI, A. G. Nutrição de monogástricos. Lavras: Universidade Federal de Lavras, 2006. 301 p.

CARVALHO, L. S. S.; FERNANDES, E. A. Formação e qualidade da casca de ovos de reprodutoras e poedeiras comerciais. Medicina Veterinária, Recife, v. 7, n. 1, p. 35-44, 2013.

COSTA, C. H. R. Teores de cálcio em dietas para codornas japonesas no terço final de postura (45 a 57 semanas de idade). Arquivo Brasileiro de Medicina Veterinária e Zootecnia, Belo Horizonte, v. 62, n. 5, p. 1225-1231, 2010.

COSTA, F. G. P.; OLIVEIRA, C. F. S.; DOURADO, L. R. B.; LIMA NETO, R. C.; CAMPOS, M. A. S. F.; LIMA, A. G. V. O. Níveis de cálcio em rações para poedeiras semipesadas após pico de postura. Revista Brasileira de Zootecnia, Viçosa, MG, v. 37, n. 4, p. 624-628, 2008.

DELL'ISOLA, A. T. P.; BAIÃO, N. C. Cálcio e fósforo para galinhas poedeiras - Avicultura. Caderno Técnico de Veterinária e Zootecnia, Belo Horizonte, n. 34, p. 65-92, 2001.

GARCIA, J.; MURAKAMI, A. E.; MARTINS, E. N.; FURLAN, A. C. Exigências nutricionais de cálcio e fósforo para codornas japonesas (Coturnix coturnix japonica) em postura. Acta Scientiarum. Animal Science, Maringá, v. 22, p. 733-739, 2000. Suplemento 2.
INSTITUTO ADOLFO LUTZ - IAL. Normas analíticas do Instituto Adolfo Lutz: métodos químicos e físicos para análise de alimentos. 2. ed. São Paulo: Instituto Adolfo Lutz, 1985. 533 p.

INSTITUTO BRASILEIRO DE GEOGRAFIA ESTATÍSTICA - IBGE. Sistema IBGE de recuperação automática. Estatística de produção pecuária. Rio de Janeiro: Censo Demográfico, 2013. Disponível em: $<$ http://www.ibge.com.br>. Acesso em: 29 ago. 2014.

ITO, D. T.; FARIA, D. E.; KUWANO, E. A.; JUNQUEIRA, O. M.; ARAUJO, L. F. Efeitos do fracionamento do cálcio dietético e granulometria do calcário sobre o desempenho e qualidade dos ovos de poedeiras comerciais. Acta Scientiarum Animal Science, Maringá, v. 28, n. 2, p. 187-195, 2006.

KESHAVARZ, K.; NAKAJIMA, S. Re-evaluation of calcium and phosphorus requirements of laying hens for optimum performance and eggshell quality. Poultry Science, Champaign, v. 72, n. 1, p. 144-153, 1993.

LIMA, C. B. Exigências nutricionais de cálcio e fósforo para mantença e ganho de peso de codornas em crescimento. 2011. Tese (Doutorado Integrado em Zootecnia) - Universidade Federal Rural de Pernambuco e Universidade Federal do Ceará, Areia.

LUZ, L. C. P. Variação granulometrica do calcário e diferentes níveis de cálcio em rações de codornas japonesas (Coturnixcoturnixjaponica). 2002. Dissertação (Mestrado em Zootecnia) - Universidade Federal de Lavras, Lavras.

MÁCHAL, L.; SIMEONOVOVÁ, J. The relationship of shortening and strength of eggshell to some egg quality indicators and egg production in hens of different initial laying lines. Archiv für Tierzucht, Dummerstorf, v. 45, n. 3, p. 287-296, 2002.

MAIORKA, A.; MACARI, M. Absorção de minerais. In: MACARI, M.; FURLAN, R. L.; GONZALES, E. Fisiologia aviária aplicada a frangos de corte. 2. ed. Jaboticabal: FUNEP; UNESP, 2002. p. 168-170.

MASUKAWA, Y.; MORAES, V. M. B.; ARIKI, J.; BRUNO, L. D. G. Níveis de cálcio da dieta sobre o desempenho e a qualidade da casca de ovos de codornas japonesas. Ars Veterinária, Jaboticabal, v. 17, n. 2, p. 144-148, 2001.

MURATA, L. S.; ARIKI, J.; SANTANA, A. P.; JARDIM FILHO, R. M. Níveis de cálcio e granulometria do calcário sobre o desempenho e qualidade da casca de ovos de poedeiras comerciais. Revista Biotemas, Florianópolis, v. 22, n. 1, p. 103-110, 2009. 
OLIVEIRA, E. G.; ALMEIDA, M. I. M. Algumas informações sobre nutrição de codornas de corte. In: SIMPÓSIO INTERNACIONAL E CONGRESSO BRASILEIRO DE COTURNICULTURA, 2.; ;1., 2004, Lavras: Universidade Federal de Lavras/NECTA, 2004. p. 53-66.

PELÍCIA, K. Efeito dos níveis de cálcio, fósforo e granulometria de calcário na dieta de poedeiras comerciais no primeiro e segundo ciclo de produção. 2008. Tese (Doutorado em Zootecnia) - Universidade Estadual Paulista, Botucatu.

PIZZOLANTE, C. C.; SALDANHA, E. S. P. B.; GARCIA, E. A.; SOUZA, H. B. A. D.; SCATOLINI, A. M.; BOIAGO, M. M. Efeito do horário de fornecimento de rações contendo diferentes níveis de cálcio sobre o desempenho produtivo e qualidade de ovos de codornas japonesas (Coturnix coturnix japonica) em final de produção. Ciência Animal Brasileira, Goiânia, v. 8, n. 4, p. 677-683, 2007.

ROSTAGNO, H. S.; ALBINO, L. F. T.; DONZELE, J. L.; GOMES, P. C.; OLIVEIRA, R. T.; LOPES, D. C.; FERREIRA, A. S.; BARRETO, S. L. T.; EUCLIDES, R. F. Tabelas brasileiras para aves e suínos - composição de alimentos e exigências nutricionais. 3. ed. Viçosa, MG: Universidade Federal de Viçosa, 2011. v. 1, 252 p.

SCHERER, C.; NUNES, R. V.; POZZA, P. C.; NUNES, C.; ROCHA, L.; KUHL, R. Avaliação dos teores de cálcio para poedeiras semipesadas durante a fase de prépostura, In: CONFERENCIA APINCO DE CIENCIA E TECNOLOGIA AVICOLA, 2004, Santos. Anais... Santos: Fundação APINCO de Ciência e Tecnologia Avícola, 2004, v. 22, p. 98.
SIBBALD, I. R.; SLINGER, S. J. A biological assay for metabolizable energy in poultry feed ingredients together with findings which demonstrate some of the problems associated with the evaluation of fats. Poultry Science, Champaign, v. 42, n. 2, p. 313-325, 1963.

SILVA, A. P. Níveis de cálcio e fósforo na dieta de codornas japonesas (Coturnixcoturnixjaponica) em diferentes fases do ciclo de produção e seus efeitos sobre o desempenho produtivo e qualidade de ovos. 2011. Dissertação (Mestrado em Zootecnia) - Universidade Estadual Paulista, Botucatu.

SILVA, D. J.; QUEIROZ, A. C. Análises de alimentos: métodos químicos e biológicos. 3. ed. Viçosa, MG: Universidade Federal de Viçosa, 2002. 235 p.

SIMÕES, A. F. Influência da atividade física no tratamento da osteoporose. Disponível em: <http://www. cdof.com.br/fisio5.htm>. Acesso em 27 dez. 2009.

VARGAS JÚNIOR, J. G.; ALBINO, L. F. T.; ROSTAGNO, H. S.; GOMES, P. C.; CUPERTINO, E. S.; CARVALHO, D. C. O.; SILVA, M. A.; PINTO, R. Níveis nutricionais de cálcio e fosforo disponível para aves de reposição leves e semipesadas de 7 a 12 semanas de idade. Revista Brasileira de Zootecnia, Viçosa, MG, v. 33, n. 4, p. 936-946, 2004. 